\title{
Hypoglycemia mediated by paraneoplastic production of Insulin like growth factor-2 from a malignant renal solitary fibrous tumor - clinical case and literature review
}

\author{
Ameer Khowaja*, Brianna Johnson-Rabbett, John Bantle and Amir Moheet
}

\begin{abstract}
Background: Hypoglycemic episodes are infrequent in individuals without a history of diabetes mellitus or bariatric surgery. When hypoglycemia does occur in such individuals, an uncommon but important diagnosis to consider is non-islet cell tumor hypoglycemia (NICTH). We report a case of NICTH associated with paraneoplastic insulin-like growth factor-2 (IGF-2) production and review current relevant medical literature.

Case presentation: A 60 year old male with no relevant past medical history was referred to the endocrinology clinic with 18 month history of episodic hypoglycemic symptoms and, on one occasion was noted to have a fingerstick glucose of $36 \mathrm{mg} / \mathrm{dL}$ while having symptoms of hypoglycemia. Basic laboratory evaluation was unrevealing. Further evaluation however showed an elevated serum IGF-2 level at $2215 \mathrm{ng} / \mathrm{mL}$ (reference range 411-1248 ng/mL). Imaging demonstrated a large right suprarenal mass. A right nephrectomy with resection of the mass demonstrated a malignant solitary fibrous tumor. Post resection, the patient's IGF-2 levels normalized and hypoglycemic symptoms resolved.
\end{abstract}

Conclusion: Due to the structural and biochemical homology between IGF-2 and insulin, elevated levels of IGF-2 can result in hypoglycemia. A posttranslational precursor to IGF-2 known as "big IGF" also possesses biologic activity. Review of recent reported cases of NICTH identified widespread anatomic locations and varied pathologic diagnoses of tumors associated with paraneoplastic production of IGF-2 causing hypoglycemia. Definitive management of hypoglycemia associated with paraneoplastic production of IGF-2 consists of resection of the tumor responsible for IGF-2 production. Accumulating literature provides a firm basis for routine IGF-2 laboratory evaluation in patients presenting with spontaneous hypoglycemia with no readily apparent cause.

Keywords: Non islet cell tumor hypoglycemia (NICTH), Insulin like Growth Factor-2 (IGF-2), Big IGF-2, Hypoglycemia, Paraneoplastic production, Insulinoma, Solitary fibrous tumor

\section{Background}

Hypoglycemia is a common medical problem in patients with diabetes mellitus treated with insulin or insulin secretagogues. Hypoglycemia is also associated with gastric bypass weight loss surgery [1].

Although rare, hypoglycemia is occasionally encountered in non-diabetic, non-gastric bypass patients. In

\footnotetext{
*Correspondence: khowa002@umn.edu

Department of Medicine, Division of Diabetes, Endocrinology and

Metabolism, University of Minnesota, 516 Delaware St SE, Minneapolis, MN 55455, USA
}

such patients, hypoglycemia is usually a manifestation of pancreatic islet cell tumors producing insulin, primary or secondary adrenal insufficiency, advanced liver disease, pheochromocytoma, IGF-1 secreting tumors, hypothyroidism, substances interfering with insulin and insulin receptor mediated metabolism [non-islet cell tumor hypoglycemia (NICTH)] or antibodies interfering with insulin receptors [2].

In subjects with recurrent hypoglycemia and no history of diabetes or weight loss surgery, NICTH is an important disorder to consider in the differential diagnosis. Tumors 
that have been reported to cause NICTH include malignancies associated with insulin receptor antibodies, tumor necrosis factor (TNF), interleukin (IL) -1 or -6; pheochromocytoma associated with excess catecholamine production; and paraneoplastic production of IGF-1 or IGF-2 [2].

In this article, we report a case of NICTH associated with paraneoplastic IGF-2 production. We have also reviewed the current literature on the subject and describe pathophysiology, diagnostic methods and treatment options.

\section{Case presentation}

A 60 year old male was referred to the Endocrinology clinic at the University of Minnesota for the evaluation of worsening symptoms that included diaphoresis, anxiety, inability to concentrate and episodic visual changes for the prior 18 months. Patient reported waking from sleep during the night with symptoms. He had discovered that carbohydrate rich snacks every $30-60$ min prevented his symptoms. As a result of frequent snacking on carbohydrate containing foods, he had gained 30 pounds in the prior 12 months. He did not experience symptoms postprandially. During one of his episodes, he obtained a finger stick glucose value of $36 \mathrm{mg} / \mathrm{dL}$. His past medical history included hypertension, dyslipidemia and obstructive sleep apnea. He did not have history of diabetes mellitus or bariatric surgery. His medications included metoprolol extended release, hydrochlorothiazide, irbesartan, amlodipine, aspirin, terazosin, simvastatin and omeprazole. He occasionally consumed alcohol and had a remote history of smoking. Physical examination was within normal limits except for body mass index (BMI) of $33.2 \mathrm{~kg} / \mathrm{m}^{2}$.

Serial finger stick blood glucose monitoring during symptomatic episodes demonstrated recurrent hypoglycemia with blood glucose values of 41, 35 and $41 \mathrm{mg} / \mathrm{dL}$. Diagnoses considered included medication induced hypoglycemia, insulinoma, chronic liver disease, pheochromocytoma and adrenal insufficiency. These diagnoses were excluded based on laboratory evaluation (Table 1).

Subsequently, IGF-2 was measured and found to be $2215 \mathrm{ng} / \mathrm{mL}$ (reference range: $414-1248 \mathrm{ng} / \mathrm{mL}$ ). Computed Tomography (CT) without contrast of chest, abdomen and pelvis showed a large right suprarenal mass measuring $14 \times 17 \times 16 \mathrm{~cm}$, which was lobular in shape with central necrosis and calcifications (Figure 1). Technetium radionuclide bone scan did not show any metastatic disease.

The patient underwent right nephrectomy and resection of the mass. Surgical pathology showed a malignant solitary fibrous tumor with spindled to epithelioid cells and focal high-grade nuclear atypia (Figure 2). The tumor cell proliferation marker Ki67 index was elevated. The tumor was positive for CD34, CD99 and Bcl-2
Table 1 Laboratory evaluation of current case

\begin{tabular}{lll}
\hline Test & Results & Reference range \\
\hline Insulin (after overnight fast) & $<2 \mathrm{mU} / \mathrm{L}$ & $0-20 \mathrm{mU} / \mathrm{L}$ \\
C-Peptide (after overnight fast) & $<0.1 \mathrm{ng} / \mathrm{mL}$ & $0.9-6.9 \mathrm{ng} / \mathrm{mL}$ \\
Plasma glucose (after overnight & $35 \mathrm{mg} / \mathrm{dL}$ & $60-99 \mathrm{mg} / \mathrm{dL}$ \\
fast) & & \\
ALT & $19 \mathrm{U} / \mathrm{L}$ & $0-70 \mathrm{U} / \mathrm{L}$ \\
AST & $27 \mathrm{U} / \mathrm{L}$ & $0-55 \mathrm{U} / \mathrm{L}$ \\
Alkaline Phosphatase & $75 \mathrm{U} / \mathrm{L}$ & $40-150 \mathrm{U} / \mathrm{L}$ \\
Total Bilirubin & $U n d e t e c t a b l e$ & $0.0-0.3 \mathrm{mg} / \mathrm{dL}$ \\
Albumin & $4.4 \mathrm{~g} / \mathrm{dL}$ & $3.3-4.9 \mathrm{~g} / \mathrm{dL}$ \\
Total Protein & $5.2 \mathrm{~g} / \mathrm{dL}$ & $6.8-8.8 \mathrm{~g} / \mathrm{dL}$ \\
Hemoglobin A1c & $4.9 \%$ & $4.0-6.0 \%$ \\
a-Fetoprotein & $5.5 \mathrm{ug} / \mathrm{L}$ & $0-8 \mathrm{ug} / \mathrm{L}$ \\
IGF-I & $<0.1 \mathrm{ug} / \mathrm{L}$ & $0-5 \mathrm{ug} / \mathrm{L}$ \\
TSH & $1.45 \mathrm{mU} / \mathrm{L}$ & $0.4-5.0 \mathrm{mU} / \mathrm{L}$ \\
Free T4 & $0.98 \mathrm{ng} / \mathrm{dL}$ & $0.70-1.85 \mathrm{ng} / \mathrm{dL}$ \\
Plasma Norepinephrine & $549 \mathrm{pg} / \mathrm{mL}$ & $80-520 \mathrm{pg} / \mathrm{mL}$ \\
Plasma free Normetanephrine & $0.65 \mathrm{mmol} / \mathrm{L}$ & $<0.9 \mathrm{mmol} / \mathrm{L}$ \\
Plasma Epinephrine & $117 \mathrm{pg} / \mathrm{mL}$ & $10-200 \mathrm{pg} / \mathrm{mL}$ \\
Plasma free Metanephrine & $0.23 \mathrm{mmol} / \mathrm{L}$ & $<0.5 \mathrm{mmol} / \mathrm{L}$ \\
Cortisol & $11 \mathrm{ug} / \mathrm{dL}$ & $4-22 \mathrm{ug} / \mathrm{dL}$ \\
Adrenocorticophic Hormone & $23 \mathrm{pg} / \mathrm{mL}$ & $<47 \mathrm{pg} / \mathrm{mL}$ \\
IGF-2 (at diagnosis) & $2215 \mathrm{ng} / \mathrm{mL}$ & $414-1248 \mathrm{ng} / \mathrm{mL}$ \\
\hline & & \\
\hline
\end{tabular}

consistent with a diagnosis of malignant solitary fibrous tumor.

The patient's follow-up IGF-2 levels were within the normal range (Table 2). He did not experience further episodes of hypoglycemia and was able to lose $10 \mathrm{lbs}$ over the next six months. A three year follow-up CT scan of the abdomen did not demonstrate any evidence of recurrence.

\section{Discussion}

The IGF-2 gene is located on short arm of chromosome 11 (11p15) adjacent to the insulin (INS) gene [3]. IGF-2 is a 67 amino acid polypeptide with $47 \%$ sequence homology with insulin. Post translational prepro IGF-2 contains 180 amino acids with a carboxy terminal peptide of 89 amino acids and a signal peptide of 24 amino acids. Prepro IGF-2 is cleaved to form mature IGF-2 [4]. Prepro IGF-2 molecules (known as "big IGF-2") have also been shown to have biologic activity and can produce hypoglycemia in the setting of a normal IGF-2 level [5]. It is due to the structural and biochemical homology between IGF-2 and insulin that an unregulated and elevated level of IGF-2 stimulates glucose metabolism pathways thus leading to hypoglycemia [6]. 


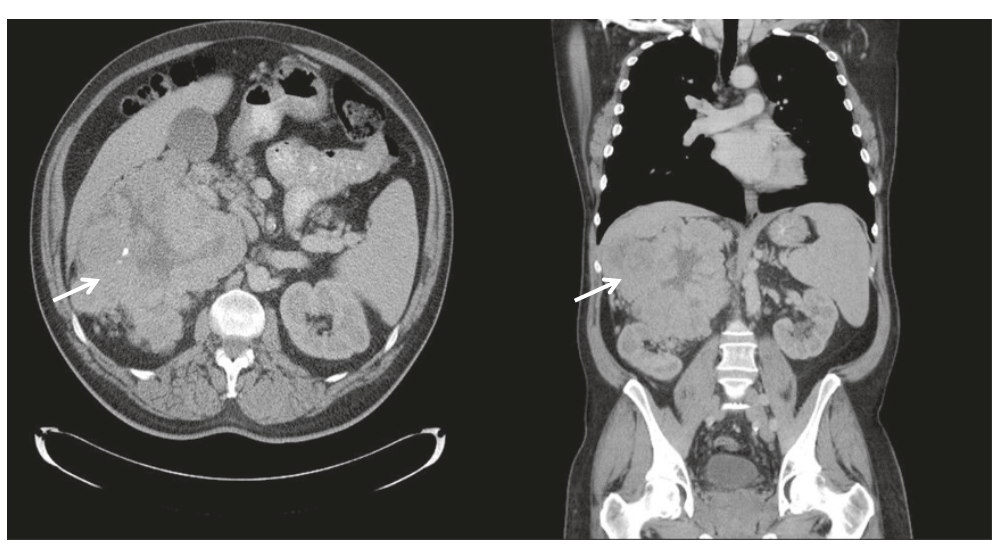

Figure 1 Non contrast Computed Tomography (CT) of chest, abdomen and pelvis; transverse and coronal views.

Under physiologic conditions, IGF-2 is mainly produced by the liver. However, other tissues may also produce IGF2 , allowing it to exert effects through endocrine, autocrine and paracrine pathways [7]. Physiologically, IGF-2 plays an important role in human fetal and post-natal development but whether it has significant physiological function in adults remain unknown [8]. As opposed to IGF-1, IGF2 regulation is independent of growth hormone [9]. IGF-1 and IGF-2 both have glucose lowering potency that is approximately $5 \%$ of insulin's potency. However, plasma concentrations of IGF-1 and IGF-2 can be 1000 times greater than insulin in NICTH allowing them to cause hypoglycemia [10]. More than $95 \%$ of IGF-2 in the circulation is bound to insulin like growth factor binding proteins (IGFBP) that have high affinity for both IGF-1 and IGF-2 [11]. In spite of structural homology with insulin, normal levels of IGF-2 do not cause hypoglycemia. At the cellular level, IGF-2 binds with IGF2R which is responsible for endocytosis, intracellular hormone transport and degradation of circulating IGF-2 [12].

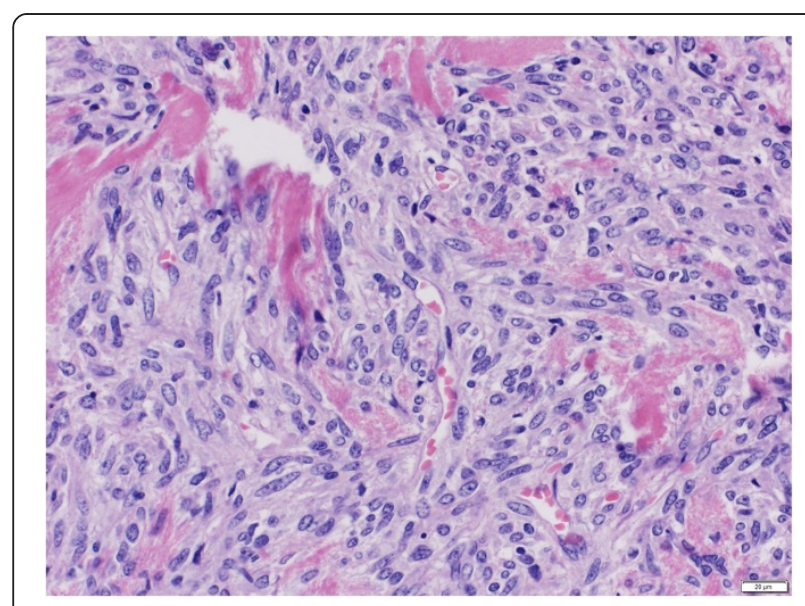

Figure 2 Hematoxylin and Eosin (H\&E) staining of surgically resected tumor. Magnification 40x.
Tumors producing elevated levels of circulating IGF-2 with resulting hypoglycemia are categorized as NICTH. $\mathrm{NICTH}$ has also been reported in conjunction with paraneoplastic production of insulin receptor antibodies, tumor necrosis factor (TNF), interleukin (IL) -1 and -6 , catecholamine (pheochromocytoma) and IGF-1 [2]. For reasons not clear, there are several neoplasms noted to have high levels of IGF-2 mRNA without exhibiting elevated hormone activity [13].

The IGF-2 gene is an imprinted gene; normally only one parental allele is expressed [14]. Loss of imprinting leads to over expression of IGF-2 and has been demonstrated in multiple tumors including solitary fibrous tumors (independent of anatomical location), Wilm's tumors, metastatic hemangiopericytomas, mesotheliomas, hepatocellular carcinomas, gastrointestinal stromal tumors (GIST), colorectal adenomas, osteosarcomas, rhabdomyosarcomas, leiomyosarcomas, paragangliomas, prostate cancers, breast cancers and bladder cancers $[2,15]$. Although these neoplasms often have elevated levels of IGF-2 mRNA, they do not always produce elevated circulating levels of IGF-2 or big IGF-2. Genetic and epigenetic mechanisms that determine isolated transcription of mRNA and the production of IGF-2 and big IGF-2 are not well understood; however, these mechanisms are thought to play an important role in carcinogenesis and tumor growth $[13,16]$.

In a previous extensive review of this topic by de Groot and coauthors in 2007, authors noted that $41 \%$ of

Table 2 Post-operative serial hormone concentration

\begin{tabular}{lll}
\hline $\begin{array}{l}\text { Time post tumor } \\
\text { resection (months) }\end{array}$ & $\begin{array}{l}\text { Serum IGF-2 level } \\
\mathbf{( 2 8 8}-\mathbf{7 3 6} \mathbf{n g} / \mathbf{m L})\end{array}$ & $\begin{array}{l}\text { Serum IGF-1 level } \\
\mathbf{( 8 1 - 2 2 5} \mathbf{~ n g} / \mathbf{m L})\end{array}$ \\
\hline $\mathbf{2}$ & 562 & 274 \\
$\mathbf{1 5}$ & 670 & 258 \\
$\mathbf{3 4}$ & 582 & 231 \\
$\mathbf{4 2}$ & 563 & 112 \\
\hline
\end{tabular}


the IGF-2 producing tumors causing hypoglycemia were of mesenchymal origin, $43 \%$ of epithelial origin, $1 \%$ of neuroendocrine and hematopoietic origin and $14 \%$ of unknown origin [2]. Although symptoms of hypoglycemia were predominant, other symptoms included skin tags, acne and rhinophyma.

We reviewed case reports of NICTH associated with paraneoplastic production of IGF-2 from 2008 to 2012 (Table 3) [17-38]. On our review of literature, we identified 22 published reports of NICTH with elevated IGF-2 levels causing hypoglycemia. Age range of the patients was $27-83$ years (mean age 58 years), with 14 males and 8 females. Predominant symptoms included those of hypoglycemia (diaphoresis, tremor, anxiety, loss of consciousness) and mechanical symptoms depending on site of the tumor. Some tumors were associated with acromegaly. The anatomic location of tumors in these case reports included liver $(\mathrm{n}=9)$, pleural cavities $(\mathrm{n}=5)$, lungs $(\mathrm{n}=3)$, retroperitoneum $(\mathrm{n}=3)$, bones $(\mathrm{n}=2)$, pelvis $(\mathrm{n}=2)$, breasts $(n=2)$, cranium $(n=1)$, kidney $(n=1)$, uterus

Table 3 Cases of hypoglycemia from NICTH secreting IGF-2 reported from 2008 till 2012

\begin{tabular}{|c|c|c|c|c|c|}
\hline Reference & Age/sex & Tumor site & Tumor pathology & Hormone elevated & Management \\
\hline$[17]$ & 28, male & Retroperitoneal pelvic region & $\begin{array}{l}\text { Malignant solitary fibrous } \\
\text { tumor }\end{array}$ & IGF-2 & $\begin{array}{l}\text { Surgical resection of } \\
\text { turmor }\end{array}$ \\
\hline$[18]$ & 68 , male & Liver & Solitary fibrous tumor & Big IGF-2 & Partial hepatic resection \\
\hline$[19]$ & 59 , male & Lungs and bones & $\begin{array}{l}\text { Meningeal } \\
\text { hemangiopericytoma }\end{array}$ & $\begin{array}{l}\text { IGF-II (elevated IGF- } \\
\text { 2/IGF-1 levels) }\end{array}$ & Interferon alpha \\
\hline$[20]$ & 75, male & Left pleural cavity & $\begin{array}{l}\text { Pleural solitary fibrous } \\
\text { tumor }\end{array}$ & Big IGF-2 & Surgical resection \\
\hline$[21]$ & 65 , male & Retroperitoneal tumor & $\begin{array}{l}\text { Retroperitoneal solitary } \\
\text { fibrous tumor }\end{array}$ & IGF-2, Big IGF-2 & Surgical resection \\
\hline$[22]$ & 66, female & Right inferior thorax & Solitary fibrous tumor & IGF-2 & Surgical resection \\
\hline$[23]$ & 53, male & Liver & $\begin{array}{l}\text { Metastatic } \\
\text { hemangiopericytoma }\end{array}$ & $\begin{array}{l}\text { Elevated IGF 2/IGF-1 } \\
\text { ratio }\end{array}$ & Right hepatectomy \\
\hline$[24]$ & 64, female & Right lower thorax & $\begin{array}{l}\text { Malignant solitary fibrous } \\
\text { tumor }\end{array}$ & Elevated IGFBP & $\begin{array}{l}\text { Surgical resection, radiation } \\
\text { post operatively }\end{array}$ \\
\hline$[25]$ & 83, male & Retroperitoneum & $\begin{array}{l}\text { Malignant solitary fibrous } \\
\text { tumor }\end{array}$ & Big IGF-2 & Surgical resection \\
\hline$[26]$ & 43, male & $\begin{array}{l}\text { Right posterior cranial fossa, metastatic lesions } \\
\text { in bilateral kidney, right iliopsoas muscle, right } \\
\text { iliac body, thoracic vertebra } 10 \text { body and } \\
\text { segment IV of the liver }\end{array}$ & $\begin{array}{l}\text { Meningeal } \\
\text { hemangiopericytoma }\end{array}$ & $\begin{array}{l}\text { Elevated IGF-2/IGF-1 } \\
\text { ratio }\end{array}$ & Adriamycin \\
\hline$[27]$ & 59, female & Right hemithorax & Solitary fibrous tumor & $\begin{array}{l}\text { Elevated IGF-2/IGF-1 } \\
\text { ratio }\end{array}$ & Surgical resection \\
\hline$[28]$ & 67, male & Pelvis & Solitary fibrous tumor & $\begin{array}{l}\text { Elevated IGF-2/IGF-1 } \\
\text { ratio }\end{array}$ & $\begin{array}{l}\text { Tumor embolization and } \\
\text { radiotherapy }\end{array}$ \\
\hline$[29]$ & 49, female & Right breast & Benign Phyllodes tumor & Big IGF-2 & Mastectomy \\
\hline$[30]$ & 49, female & Left breast & $\begin{array}{l}\text { High grade Phyllodes } \\
\text { sarcoma }\end{array}$ & Big IGF-2 & Mastectomy \\
\hline$[31]$ & 80, female & Uterus & Uterine leiomyoma & $\begin{array}{l}\text { IGF-II, elevated IGF- } \\
\text { 2/IGF-1 ratio }\end{array}$ & Exploratory laparotomy \\
\hline$[32]$ & 69, male & Spleen, lungs, liver & Hepatocellular carcinoma & $\begin{array}{l}\text { Elevated IGF-2 } \\
\text { mRNA expression }\end{array}$ & \\
\hline$[33]$ & 61, male & Liver & $\begin{array}{l}\text { Poorly differentiated } \\
\text { gastric adenocarcinoma }\end{array}$ & $\begin{array}{l}\text { Big IGF-2, elevated } \\
\text { IGF-2/IGF-1 ratio }\end{array}$ & Gastrectomy \\
\hline$[34]$ & 27, female & Lung and liver & Ovarian germ cell tumor & Big IGF-2 & $\begin{array}{l}\text { Dexamethasone, } \\
\text { recombinant Growth } \\
\text { hormone }\end{array}$ \\
\hline$[35]$ & 53, female & Right adrenal gland, liver & & $\begin{array}{l}\text { Elevated IGF-2/IGF-1 } \\
\text { ratio }\end{array}$ & Phenoxybenzamine \\
\hline$[36]$ & 45, Male & Pelvis and peritoneum & $\begin{array}{l}\text { Desmoplastic small } \\
\text { round cell tumor }\end{array}$ & $\begin{array}{l}\text { Elvated IGF-2 and } \\
\text { IGF-2/IGF-1 ratio }\end{array}$ & chemotherapy \\
\hline$[37]$ & 77, male & Liver and lungs & Hepatocellular carcinoma & Big IGF-2 & chemotherapy \\
\hline$[38]$ & 41, male & Pleura and posterior mediastinum & Solitary fibrous tumor & Big IGF-2 & chemotherapy \\
\hline
\end{tabular}


$(\mathrm{n}=1)$, spleen $(\mathrm{n}=1)$ and adrenal gland $(\mathrm{n}=1)$. The tumor involved more than one organ system in 6 patients. Fifteen patients were diagnosed with NICTH for the first time, whereas 7 patients presented with recurrent disease. Pathologic diagnosis included solitary fibrous tumor $(\mathrm{n}=10)$, hemangiopericytoma $(\mathrm{n}=3)$, phyllodes tumor and sarcoma $(\mathrm{n}=2)$, hepatocellular carcinoma $(\mathrm{n}=2)$, uterine leiomyoma $(\mathrm{n}=1)$, gastric adenocarcinoma $(n=1)$, ovarian germ cell tumor $(n=1)$, pheochromocytoma $(\mathrm{n}=1)$ and desmoplastic small round cell tumor $(\mathrm{n}=1)$. Hypoglycemia associated with IGF-2 production has also been reported in pancreatic islet cell tumor [39]. Biochemical profiles of the patients varied and included elevated IGF-2, elevated big IGF-2 with normal IGF-2, and elevated IGF-2 to IGF-1 ratio.

Currently, different assays are being used in clinical and research settings for measurement of IGF-2. These assays utilize liquid chromatography-mass spectrometry (LC-MS) [40] or immunoassay (ELISA and RIA). Western blot is used for measurement big IGF-2 [41]. The possibility of NICTH secondary to IGF-2 is suggested by low blood glucose along with suppressed insulin, Cpeptide and IGF-1 levels. Concurrent normal to high morning cortisol and normal response on cosyntropin stimulation can rule out adrenal insufficiency and suggest NICTH secondary to IGF-2. IGF-2 levels are frequently within the normal range in $\mathrm{NICTH}$, and assays for big IGF-2 are not commercially available. Thus, the IGF-2: IGF-1 ratio is used as a surrogate marker for big IGF-2 concentration. A ratio of $>10$ is considered to be clinically significant [42].

Management of NICTH can be divided into issues related to 1) hypoglycemia and 2) the underlying tumor. Hypoglycemia can be managed in a typical manner by administration of oral glucose, intravenous dextrose or glucagon depending upon the severity. Glucocorticoid therapy has been shown to suppress big IGF-2 in a dose dependent manner using doses of 30-60 mg/d of prednisolone or $4 \mathrm{mg} / \mathrm{d}$ of dexamethasone [43]. Surgical resection of the tumor, whenever possible, is the treatment of choice and, if successful, usually results in the resolution of hypoglycemia and other metabolic abnormalities. In cases where complete resection is not feasible due to tumor infiltration and/or distant metastasis, surgical debulking along with chemoradiation can be considered for treatment of hypoglycemia. The choice of chemotherapy depends upon the primary pathology of the tumor. Metastatic disease and tumor recurrence are associated with a poor prognosis.

\section{Conclusion}

NICTH is a rare cause of hypoglycemia in the general population. It is associated with elevated levels of IGF-2, high molecular weight IGF-2 (big-IGF-2) or an increased
IGF-2 to IGF-1 ratio. Diagnosis of paraneoplastic IGF-2 induced hypoglycemia is an important and time sensitive consideration since earlier detection of tumors provides a better opportunity for complete resection and subsequent resolution of hypoglycemia. Whether IGF-2 level should be routinely measured in the evaluation of hypoglycemia depends on the prevalence of the condition. Accumulating literature supports screening for IGF-2 in non-diabetic individuals who present with hypoglycemia along with suppressed insulin and c-peptide levels.

\section{Consent}

Written informed consent was obtained from the patient for publication of this case report and accompanying images. A copy of the written consent is available for review.

\section{Abbreviations \\ IGF-1: Insulin like growth factor-1; IGF-2: Insulin like growth factor-2; NICTH: Non-islet cell tumor hypoglycemia; TNF: Tumor necrosis factor; IL: Interleukin; BMI: Body mass index; CT: Computed tomography; LC-MS: Liquid chromatography-mass spectrometry.}

\section{Competing interest}

The authors declare that they have no competing interests.

\section{Authors' contribution}

AK reviewed the literature and wrote the manuscript. BJR edited the manuscript, wrote the abstract and participated in the literature review. JB was involved in clinical management and reviewed and edited the manuscript. AM was involved in clinical management and reviewed and edited the manuscript. All authors read and approved the final manuscript.

Received: 9 December 2013 Accepted: 5 June 2014

Published: 17 June 2014

\section{References}

1. Vella A, Service FJ: Incretin hypersecretion in post-gastric bypass hypoglycemia: primary problem or red herring? J Clin Endocrinol Metab 2007, 92:4563-4565.

2. de Groot JW, Rikhof B, van Doorn J, Bilo HJ, Alleman MA, Honkoop AH, van der Graaf WT: Non-islet cell tumour-induced hypoglycaemia: a review of the literature including two new cases. Endocr Relat Cancer 2007, 14:979-993.

3. Bell Gl, Gerhard DS, Fong NM, Sanchez-Pescador R, Rall LB: Isolation of the human insulin-like growth factor genes: insulin-like growth factor II and insulin genes are contiguous. Proc Natl Acad Sci U S A 1985, 82:6450-6454.

4. O'Dell SD, Day IN: Insulin-like growth factor II (IGF-II). Int J Biochem Cell Biol 1998, 30:767-771.

5. Alkemade GM, Bakker M, Rikhof B, ljpma FF, van Ginkel RJ, Kluin PM, van Doorn J, Dullaart RP: Hypoglycemia in a Patient With a Big "Big"-IGF-IIProducing Tumor. J Clin Endocrinol Metab 2013, 98:3113-3114.

6. Hoekman K, van Doorn J, Gloudemans T, Maassen JA, Schuller AG, Pinedo HM: Hypoglycaemia associated with the production of insulin-like growth factor II and insulin-like growth factor binding protein 6 by a haemangiopericytoma. Clin Endocrinol (Oxf) 1999, 51:247-253.

7. Butler AA, Le Roith D: Control of growth by the somatropic axis: growth hormone and the insulin-like growth factors have related and independent roles. Annu Rev Physiol 2001, 63:141-164.

8. Han VK, D'Ercole AJ, Lund PK: Cellular localization of somatomedin (insulin-like growth factor) messenger RNA in the human fetus. Science 1987, 236:193-197.

9. Jones J, Clemmons DR: Insulin-like growth factors and their binding proteins: biological actions. Endocr Rev 1995, 16:3-34.

10. Baxter RC: The insulin-like growth factors and their binding proteins. Comp Biochem Physiol B 1988, 91:229-235.

11. Humbel RE: Insulin-like growth factors I and II. Eur J Biochem 1990, 190:445-462. 
12. Malaguarnera R, Belfiore A: The Emerging Role of Insulin and Insulin-Like Growth Factor Signaling in Cancer Stem Cells. Front Endocrinol (Lausanne) 2014, 5:10. eCollection 2014.

13. Tennant MK, Thrasher JB, Twomey PA, Drivdahl RH, Birnbaum RS, Plymate SR: Protein and messenger ribonucleic acid (mRNA) for the type 1 insulin-like growth factor (IGF) receptor is decreased and IGF-II mRNA is increased in human prostate carcinoma compared to benign prostate epithelium. J Clin Endocrinol Metab 1996, 81:3774-3782.

14. Lewis A, Reik W: How imprinting centres work. Cytogenet Genome Res 2006, 113:81-89.

15. Gallagher EJ, LeRoith D: The proliferating role of insulin and insulin-like growth factors in cancer. Trends Endocrinol Metab 2010, 21:610-618.

16. Tricoli J, Rall LB, Karakousis CP, Herrera L, Petrelli NJ, Bell Gl, Shows TB: Enhanced levels of insulin-like growth factor messenger RNA in human colon carcinomas and liposarcomas. Cancer Res 1986, 46:6169-6173.

17. Wagner S, Greco F, Hamza A, Hoda RM, Holzhausen HJ, Fornara P: Retroperitoneal malignant solitary fibrous tumor of the small pelvis causing recurrent hypoglycemia by secretion of insulin-like growth factor 2. Eur Urol 2009, 55:739-742.

18. Fama F, Le Bouc Y, Barrande G, Villeneuve A, Berry MG, Pidoto RR, Saint Marc O: Solitary fibrous tumour of the liver with IGF-II-related hypoglycaemia. A case report. Langenbecks Arch Surg 2008, 393:611-616.

19. Anaforoglu I, Simsek A, Turan T, Algun E: Hemangiopericytoma-associated hypoglycemia improved by glucocorticoid therapy: a case report. Endocrine 2009, 36:151-154.

20. Tani Y, Tateno T, Izumiyama H, Doi M, Yoshimoto T, Hirata Y: Defective expression of prohormoneconvertase 4 and enhanced expression of insulin-like growth factor II by pleural solitary fibrous tumor causing hypoglycemia. Endocr J 2008, 55:905-911.

21. Yamakawa-Yokota F, Ozaki N, Okajima A, Nishio H, Nagasaka T, Oiso Y: Retroperitoneal solitary fibrous tumor-induced hypoglycemia associated with high molecular weight insulin-like growth factor II. Clin Med Res 2010, 8:159-162.

22. Okabe $\mathrm{R}$, Sonobe $\mathrm{M}$, Bando $\mathrm{T}$, Date $\mathrm{H}$ : Large solitary fibrous tumor with overexpression of insulin-like growth factor-2. Interact Cardiovasc Thorac Surg 2010, 11:688-690.

23. Lawson EA, Zhang X, Crocker JT, Wang WL, Klibanski A: Hypoglycemia from IGF2 overexpression associated with activation of fetal promoters and loss of imprinting in a metastatic hemangiopericytoma. J Clin Endocrinol Metab 2009, 94:2226-2231.

24. Hu Y, Mahar TJ, Hicks DG, Raymond D, Jones C, Wandtke JC, Powers JM, Xu $\mathrm{H}$ : Malignant solitary fibrous tumor: report of 3 cases with unusual features. Appl Immunohistochem Mol Morphol 2009, 17:451-457.

25. Hata T, Tsuruta Y, Takamori S, Shishikura Y: Non-islet cell tumor hypoglycemia at the second recurrence of malignant solitary fibrous tumor in the retroperitoneum and pelvis: a case report. Case Rep Oncol 2012, 5:420-427.

26. Chan JK, Cheuk W, Ho LC, Wen JM: Recurrent meningeal hemangiopericytoma with multiple metastasis and hypoglycemia: a case report. Case Rep Med 2012, 2012:628756.

27. Thabit H, Healy ML, Royston D, Broe P, Scarramuzzi N, Walsh TN, Sreenan S: A case of spontaneous hypoglycaemia and impaired glucose tolerance in the same patient. Ann Clin Biochem 2011, 48:183-185.

28. Krishnan L, Clark J: Non-islet cell tumour hypoglycaemia. BMJ Case Rep 2011, doi:10.1136/bcr.02.2011.3914.

29. Hino N, Nakagawa Y, Ikushima Y, Yoshida M, Tsuyuguchi M: A case of a giant phyllodes tumor of the breast with hypoglycemia caused by high-molecular-weight insulin-like growth factor II. Breast Cancer 2010 17:142-145

30. Renard E, Langbour-Remy C, Klein M, Le Bouc Y, Weryha G, Cuny T: Severe hypoglycemia with "Big"-IGF-2 oversecretion by a giant phyllode tumor of the breast: a rare case of non-islet cell tumor-induced hypoglycemia (NICTH). Ann Endocrinol 2012, 73:488-491.

31. Ndzengue A, Deribe Z, Rafal RB, Mora M, Desgrottes S, Schmidt F, Becher R, Wright AM, Guillaume J, Jaffe EA: Non-islet cell tumor hypoglycemia associated with uterine leiomyomata. Endocr Pract 2011, 17:e109-e112.

32. Matsuyama M, Sugiura S, Kakita A, Sato Y, Kuroda M: Hepatocellular carcinoma arising from ectopic liver tissue in the spleen producing insulin-like growth factor II. Pathol Res Pract 2011, 207:124-126.

33. Maruyama H, Tatsumi M, Kitayama H, Enomoto $Y$, Kuniyasu H, Uematsu K, Fukuda I, Kameya T, Konishi Y: A case of gastric cancer with non-islet cell tumor hypoglycemia detected by insulin-like growth factor II. Pathol Int 2010, 60:595-597.

34. Powter L, Phillips S, Husbands E: A case report of non-islet cell tumourhypoglycaemia associated with ovarian germ-cell tumour. Palliat Med 2013, 27:281-283.

35. Macfarlane DP, Leese GP: Hypoglycaemia, phaeochromocytoma and features of acromegaly: a unifying diagnosis? QJM 2011, 104:983-986.

36. Barra WF, Castro G, Hoff AO, Siqueira SA, Hoff PM: Symptomatic hypoglycemia related to inappropriately high igf-ii serum levels in a patient with desmoplastic small round cell tumor. Case Rep Med 2010, 2010:684045.

37. Okushin K, Asaoka Y, Fukuda I, Fujiwara N, Minami T, Sato M, Mikami S, Uchino K, Enooku K, Kondo Y, Tateishi R, Goto T, Shiina S, Yoshida H, Koike K: IGF-II Producing Hepatocellular Carcinoma Treated with Sorafenib: Metabolic Complications and a Foresight to Molecular Targeting Therapy to the IGF Signal. Case Rep Gastroenterol 2012, 6:784-789.

38. Tominaga N, Kawarasaki C, Kanemoto K, Yokochi A, Sugino K, Hatanaka K, Uekusa T, Fukuda I, Aiba M, Hizuka N, Uda S: Recurrent solitary fibrous tumor of the pleura with malignant transformation and non-islet cell tumor-induced hypoglycemia due to paraneoplastic overexpression and secretion of high-molecular-weight insulin-like growth Factor II. Intern Med 2012, 51:3267-3272

39. Chung JO, Hong SI, Cho DH, Lee JH, Chung DJ, Chung MY: Hypoglycemia associated with the production of insulin-like growth factor II in a pancreatic islet cell tumor: a case report. Endocr J 2008, 55:607-612.

40. Bystrom C, Sheng S, Zhang K, Caulfield M, Clarke NJ, Reitz R: Clinical utility of insulin-like growth factor 1 and 2; determination by high resolution mass spectrometry. PLoS One 2012, 7:e43457.

41. Qiu Q, Yan X, Bell M, Di J, Tsang BK, Gruslin A: Mature IGF-II prevents the formation of "big" IGF-II/IGFBP-2 complex in the human circulation. Growth Horm IGF Res 2010, 20:110-117.

42. Marks V, Teale JD: Tumours producing hypoglycaemia. Endocr Relat Cancer 1998, 5:111-129.

43. Teale JD, Marks V: Glucocorticoid therapy suppresses abnormal secretion of big IGF-II by non-islet cell tumours inducing hypoglycaemia (NICTH). Clin Endocrinol 1998, 49:491-498.

\section{doi:10.1186/1472-6823-14-49}

Cite this article as: Khowaja et al:: Hypoglycemia mediated by paraneoplastic production of Insulin like growth factor-2 from a malignant renal solitary fibrous tumor - clinical case and literature review. BMC Endocrine Disorders 2014 14:49.

\section{Submit your next manuscript to BioMed Central and take full advantage of:}

- Convenient online submission

- Thorough peer review

- No space constraints or color figure charges

- Immediate publication on acceptance

- Inclusion in PubMed, CAS, Scopus and Google Scholar

- Research which is freely available for redistribution 